\title{
Quantification of Thioguanine in DNA Using Liquid Chromatography-Tandem Mass Spectrometry for Routine Thiopurine Drug Monitoring in Patients With Pediatric Acute Lymphoblastic Leukemia
}

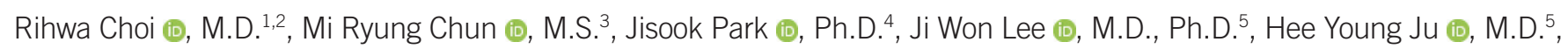

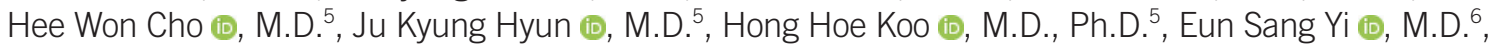
and Soo-Youn Lee (1D, M.D., Ph.D. 1,3,7,8

${ }^{1}$ Department of Laboratory Medicine and Genetics, Sungkyunkwan University School of Medicine, Seoul, Korea; ${ }^{2}$ Department of Laboratory Medicine, Green Cross Laboratories, Yongin, Korea; ${ }^{3}$ Department of Laboratory Medicine and Genetics, Samsung Medical Center, Seoul, Korea; ${ }^{4}$ Samsung Biomedical Research Institute, Samsung Medical Center, Sungkyunkwan University School of Medicine, Seoul, Korea; ${ }^{5}$ Department of Pediatrics, Samsung Medical Center, Sungkyunkwan University School of Medicine, Seoul, Korea; ${ }^{6}$ Department of Pediatrics, Korea University Guro Hospital, Korea University College of Medicine, Seoul, Korea; ' Department of Clinical Pharmacology and Therapeutics, Samsung Medical Center, Sungkyunkwan University School of Medicine, Seoul, Korea; ${ }^{8}$ Department of Health Science and Technology, Samsung Advanced Institute of Health Science and Technology, Sungkyunkwan University, Seoul, Korea

Background: We developed an assay to measure DNA-incorporated 6-thioguanine (DNATG) and validated its clinical applicability in Korean pediatric patients with acute lymphoblastic leukemia (ALL) in order to improve individualized thiopurine treatment and reduce the life-threatening cytotoxicity.

Methods: The DNA-TG assay was developed based on liquid chromatography-tandem mass spectrometry, with isotope-labeled TG-d3 and guanine-d3 as internal standards. This method was applied to 257 samples of pediatric ALL patients. The DNA-TG level was compared with erythrocyte TG nucleotide (RBC-TGN) level in relation to the TPMT and NUDT15 genotypes, which affect thiopurine metabolism, using Spearman's rank test and repeated measure ANOVA.

Results: For DNA-TG quantification, a linearity range of 10.0-5,000.0 fmol TG/ug DNA; bias for accuracy of $-10.4 \%-3.5 \%$; coefficient of variation for intra- and inter-day precision of $3.4 \%$ and $5.8 \%$ at $80 \mathrm{fmol}$ TG/ $\mathrm{\mu g}$ DNA and of $4.9 \%$ and $5.3 \%$ at $800 \mathrm{fmol} \mathrm{TG} / \mathrm{\mu g}$ DNA, respectively; and recovery of $85.7 \%-116.2 \%$ were achieved without matrix effects or carry-over. The median DNA-TG level in the 257 samples was $106.0 \mathrm{fmol}$ TG/ug DNA (interquartile range, 75.8-150.9). There was a strong correlation between DNA-TG and RBC-TGN levels $(\rho=0.68, P<0.0001)$. The DNA-TG/RBC-TGN ratio was significantly higher in NUDT15 intermediate metabolizers $\left({ }^{*} 1 /{ }^{*} 2\right.$ and $\left.{ }^{*} 1 /{ }^{*} 3\right)$ than in patients with wildtype alleles $(P<0.0001)$.

Conclusions: This simple and sensitive method for measuring DNA-TG level can improve therapeutic drug monitoring for thiopurine treatment.

Key Words: DNA-incorporated 6-thioguanine, Liquid chromatography-tandem mass spectrometry, Therapeutic drug monitoring, Thiopurine, TPMT, NUDT15
Received: February 14, 2020

Revision received: May 3, 2020

Accepted: September 19, 2020

\section{Corresponding author:}

Soo-Youn Lee, M.D., Ph.D.

Department of Laboratory Medicine and Genetics, Department of Clinical Pharmacology and Therapeutics, Samsung Medical Center, Sungkyunkwan University School of Medicine, 81 Irwon-ro, Gangnam-gu, Seoul 06351, Korea; Department of Health Science and Technology, Samsung Advanced Institute of Health Science and Technology, Sungkyunkwan University, 115 Irwon-ro, Gangnam-gu, Seoul 06355, Korea

Tel: +82-2-3410-1834

Fax: +82-2-3410-2719

E-mail: suddenbz@skku.edu

\section{Co-corresponding author:}

Ji Won Lee, M.D., Ph.D.

Department of Pediatrics, Samsung Medical Center, Sungkyunkwan University School of Medicine, 81 Irwon-ro, Gangnam-gu, Seoul 06351, Korea

Tel: +82-2-3410-0659

Fax: +82-2-3410-0049

E-mail: leejw.lee@samsung.com

\section{(c) (1) (8)}

C) Korean Society for Laboratory Medicine This is an Open Access article distributed under the terms of the Creative Commons Attribution Non-Commercial License (https://creativecommons.org/licenses/by-nc/4.0) which permits unrestricted non-commercial use, distribution, and reproduction in any medium, provided the original work is properly cited. 


\section{INTRODUCTION}

Mercaptopurine (6-MP; 3,7-dihydropurine-6-thione), a thiopurine drug, is widely used in the treatment of acute lymphoblastic leukemia (ALL) [1]. Therapeutic drug monitoring of thiopurine drugs has been accomplished by the quantification of thiopurine metabolites in various cells and cell compartments, including erythrocytes (RBC), whole blood, and leukocyte DNA [1-3]. Among diverse cellular metabolites, DNA-incorporated 6-thioguanine (DNA-TG) has been suggested as a more relevant thiopurine metabolite than erythrocyte TG nucleotides (RBC-TGN), because RBCs are not the drug target $[1,4,5]$. However, most clinical laboratories measure RBC-TGN level on the basis of clinical guidelines for the use of RBC-TGN level for therapeutic drug monitoring of thiopurine drugs in inflammatory bowel disease (another disease treated with thiopurine drugs with different regimen). In fact, a few clinical laboratories outside South Korea measure DNA-TG level; however, to the best of our knowledge, there is no clinical laboratory measuring DNA-TG level in South Korea [1, 5, 7].

For therapeutic monitoring of thiopurine drugs, an accurate, precise, simple, and sensitive method measuring thiopurine metabolites is needed [6, 7]. Liquid chromatography-tandem mass spectrometry (LC-MS/MS) involves various protocols and specifications, including reagents, standards, calibrators, and/or sample preparation methods, as well as instrument conditions and settings, leading to significant laboratory-to-laboratory variability for the same analyte. Therefore, there is a need for an LCMS/MS-based analytical method that is suitable for clinical application [6, 8]. Previous studies on DNA-TG level involved complex methods, using different cell lines and time-consuming culture processes $[1,5,7]$.

The pharmacogenetics and kinetics of thiopurine metabolism are complex (https://www.pharmgkb.org/pathway/PA2040 [9]), and there is extensive interindividual variation in drug metabolism and drug-induced toxicity, such as life-threatening myelosuppression, hepatotoxicity, skin rash, and alopecia [4, 10]. Patients harboring two loss-of-function TPMT (gene encodes thiopurine S-methyltransferase) alleles (homozygous or compound heterozygous TPMT alleles) are at very high risk of life-threatening myelosuppression, which is associated with very high TGN levels [10]. It has been recently suggested that loss-of-function in NUDT15 (Nudix hydrolase 15) alleles cause thiopurine-induced cytotoxicity, because NUDT15 catalyzes the conversion of cytotoxic thioguanine triphosphate (TGTP) metabolites to the less toxic thioguanine monophosphate, and defects in NUDT15- mediated degradation of TGTP result in more TGTP being available for incorporation into DNA [5, 10].

We aimed to develop an assay to measure DNA-TG level in nucleated blood cells in etheno-derivatized samples using LCMS/MS and to validate the method and its clinical applicability in Korean pediatric patients with ALL treated with 6-MP with TPMT and NUDT15 genotypes. This is the first LC-MS/MS method for measuring DNA-TG level, enabling quantification of TG in a small volume of DNA (only $1 \mu \mathrm{g}$ ), with genetic analysis for TPMT and NUDT15 in Korean pediatric patients with ALL.

\section{MATERIALS AND METHODS}

\section{Patient information}

The study population comprised pediatric ALL patients treated with 6-MP at the Pediatric Department of Samsung Medical Center, Seoul, Korea. Between January 2018 and May 2019, 60 pediatric ALL patients were prospectively recruited and followed up. The inclusion criterion was age at ALL diagnosis $<19$ years. The exclusion criteria were as follows: 6-MP dose information was not available, DNA-TG level was not measured at steady state, RBC-TGN and DNA-TG levels were not measured simultaneously. TPMT and NUDT15 genotyping was performed before initiating 6-MP treatment, according to previously described methods [12, 25], and the results were obtained via medical record review. RBC-TGN and DNA-TG levels were measured simultaneously in patient samples collected at least 14 days after initiation of constant-dosing 6-MP treatment (median dose 17.3, interquartile range [IQR] 9.8-24.1 mg/day $/ \mathrm{m}^{2}$ ). RBC and DNA (extracted from leukocytes) samples were stored at $-80^{\circ} \mathrm{C}$ for approximately six months until analysis. Among the 60 pediatric ALL patients consecutively enrolled, 55 (34 boys and 21 girls) with ALL treated with 6-MP and simultaneous measurements of RBC-TGN and DNA-TG levels were included in this study. In total, 273 measurement pairs for RBC-TGN and DNA-TG levels were collected. Among these, 257 measurements from 54 children (34 boys and 20 girls) were taken at steady state. Drug-free DNA for pooling as blank DNA for the development and validation for DNA-TG measurement was obtained from 20 volunteers who were not exposed to mercaptopurine. This study was conducted in accordance with the Declaration of Helsinki, and written informed consent was obtained from the parents or legal guardians of all patients and volunteers. This study was approved by the Institutional Review Board of Samsung Medical Center (file No. SMC 2017-11-161). 


\section{Method development for DNA-TG measurement}

The reagents for this study were purchased from Sigma-Aldrich (St. Louis, MO, USA). TG, TG-d3, and guanine (G)-d3 were obtained from Toronto Research Chemicals (Ontario, Canada) and were stored at $-30^{\circ} \mathrm{C}$. DNA was extracted from EDTA-treated blood using a MagNA Pure 96 system (Roche Diagnostics International Ltd., Rotkreuz, Switzerland), according to the manufacturer's instructions. Samples for LC-MS/MS were prepared as described previously $[1,7]$, with the following modifications: 1 $\mu \mathrm{g}$ of DNA in $75 \mu \mathrm{L}$ of de-ionized water was incubated with 75 $\mu \mathrm{L}$ of derivatization buffer (1 M chloroacetaldehyde in $90 \mathrm{mM}$ potassium phosphate at $\mathrm{pH} 5.0$ ) at $99.9^{\circ} \mathrm{C}$ for three hours. The sample was mixed with $800 \mu \mathrm{L}$ of $0.2 \%$ formic acid. After conditioning and equilibration with $800 \mu \mathrm{L}$ each of methanol and $0.1 \%$ formic acid, $1 \mathrm{~mL}$ of the sample was loaded on a solidphase extraction (SPE) column (Strata X-C, $33 \mu \mathrm{m}$ particle size, $30 \mathrm{mg} / \mathrm{mL} /$ well; Phenomenex, Torrance, CA, USA). The adsorbed sample was washed with $800 \mu \mathrm{L}$ of $0.1 \%$ formic acid and $800 \mu \mathrm{L}$ of $0.1 \%$ formic acid in $50 \%$ methanol and then eluted with $300 \mu \mathrm{L}$ of $780 \mathrm{mM}$ ammonium hydroxide in $50 \%$ methanol. The eluate was dried at $40^{\circ} \mathrm{C}$ under streaming nitrogen and reconstituted in $150 \mu \mathrm{L}$ of $0.1 \%$ formic acid in $95 \%$ acetonitrile.

Calibrators were generated by spiking 10, 20, 100, 1,000, and 5,000 fmol TG into $1 \mu \mathrm{g}$ pooled drug-free DNA from 20 volunteers who were not exposed to mercaptopurine. Two samples for daily quality control (QC) were prepared at concentrations of 80 and $800 \mathrm{fmol}$ TG/ug DNA using Jurkat cells [7]. It was assumed that TG spiked into a blank DNA sample and TG incorporated into DNA are derivatized equally [7]. An internal standard (IS) solution containing etheno-TG-d3 and etheno-G-d3 was prepared by derivatization of TG-d3 and G-d3 SPE [7]. A working IS solution with $1 \mu \mathrm{g} / \mathrm{mL}$ etheno-TG-d3 and $2 \mu \mathrm{g} / \mathrm{mL}$ etheno-G-d3 was prepared by diluting the stock IS in distilled water. The IS was added to all samples at the level of SPE eluate.

Chromatographic separation was carried out using an Acquity UPLC System (Waters, Milford, MA, USA) coupled to a XEVO TQ-S tandem quadrupole mass spectrometer (Waters) equipped with an ethylene-bridged hybrid hydrophilic interaction LC column $(2.1 \times 100 \mathrm{~mm}, 1.7 \mu \mathrm{m}$; Waters). Injection volume was 5 $\mu \mathrm{L}$, and total run time was $6 \mathrm{~min} / \mathrm{sample}$. Quantitative analysis was performed in the multiple reaction-monitoring mode with positive electrospray ionization $(\mathrm{m} / \mathrm{z} 234.0 \rightarrow 191.1$ for ethenoTG, $237.0 \rightarrow 194.1$ for etheno-TG-d3, 176.1 $\rightarrow 94.1$ for ethenoG, and $179.1 \rightarrow 94.1$ for etheno-G-d3). Gradient elution is summarized in Table 1. For optimization, the MS instrument settings
Table 1. Gradient conditions for chromatographic separation for DNA-TG quantification

\begin{tabular}{lcccc}
\hline \multirow{2}{*}{ Time segment } & \multirow{2}{*}{$\begin{array}{c}\text { Time } \\
(\mathrm{min})\end{array}$} & $\begin{array}{c}\text { Flow rate } \\
(\mu \mathrm{L} / \mathrm{min})\end{array}$ & \multicolumn{2}{c}{ Mobile phase } \\
\cline { 5 - 5 } \cline { 4 - 5 } & & $\mathrm{A}^{*}$ & $\% \mathrm{~B}^{\dagger}$ \\
\hline 2 & Initial & 0.35 & 0 & 100 \\
3 & 1.5 & 0.35 & 0 & 100 \\
4 & 1.8 & 0.45 & 0 & 100 \\
5 & 2.7 & 0.45 & 0 & 100 \\
6 & 3.2 & 0.45 & 70 & 30 \\
7 & 3.7 & 0.45 & 70 & 30 \\
\hline
\end{tabular}

${ }^{\star} 0.1 \%$ formic acid in distilled water; ${ }^{\dagger} 160 \mathrm{mM}$ formic acid and $10 \mathrm{mM}$ ammonium formate in $95 \%$ acetonitrile.

Abbreviation: DNA-TG, DNA-incorporated 6-thioguanine.

were as follows: source temperature, $150^{\circ} \mathrm{C}$; desolvation temperature, $550^{\circ} \mathrm{C}$; capillary voltage, $3 \mathrm{kV}$; cone gas flow, $150 \mathrm{~L} / \mathrm{hr}$; desolvation gas flow, $800 \mathrm{~L} / \mathrm{hr}$; and collision gas flow $0.16 \mathrm{~mL} / \mathrm{min}$.

The MS response area was corrected with isotope-labeled TGd3 and G-d3. Chromatographic etheno-TG peaks were normalized using etheno- $G$ by calculating $T G$ responses as etheno- $T G$ area/etheno- $G$ area (DNA-TG $=$ [etheno- $T G$ response/etheno- $G$ response]/[etheno-TG-d3 response/etheno-G-d3 response]).

\section{Method validation for DNA-TG quantification}

Accuracy, precision, linearity, recovery, matrix effect, and carryover were validated according to previous literature and current guidelines for MS [6, 8, 17-21]. Daily calibration curves were generated from five calibrators (10,20, 100, 1,000, and 5,000 $\mathrm{fmol} \mathrm{TG} / \mathrm{\mu g} \mathrm{DNA}$ ) in parallel with unknown samples. Two QC samples at concentrations of 80 and $800 \mathrm{fmol} \mathrm{TG} / \mathrm{\mu g}$ DNA were used to determine intra- (five independent analytical runs) and inter-day (five days) accuracy and precision. To determine the lower limit of quantification (LLOQ), control samples with 10 fmol TG were spiked into $1 \mu \mathrm{g}$ DNA and tested in five replicated runs over three days. The LLOQ was determined with a signalto-noise ratio $>10$, coefficient of variation $(\mathrm{CV})<20 \%$, and bias $<20 \%[6,8,19]$. Method selectivity and extraction recovery were evaluated using DNA samples from healthy volunteers who had not received 6-MP treatment. SPE recovery efficiency was evaluated in triplicate by spiking approximately $100 \mathrm{fmol}$ etheno-TG into $1 \mu \mathrm{g}$ of DNA in either the derivatized sample or from the SPE column eluate before LC-MS/MS quantification. Extraction recovery was calculated as follows: extraction recovery $(\%)=$ area of derivatized sample/area of elute ${ }^{*} 100$. Because addition of exogenous calibrators would not be a suitable 
equivalent measure of the efficiency of extraction from DNA, recovery analysis was limited to testing SPE recovery [1]. The effect of DNA on quantification was investigated by analyzing two linear calibration curves plotted for calibrators spiked into control DNA and distilled water, and the slopes were compared as described by Jacobsen, et al. [7]. Carry-over was investigated based on the response area of blank DNA samples measured immediately after measuring DNA samples containing 5,000 fmol TG/ug DNA. No significant carry-over was defined as response areas of the blank DNA sample being $<20 \%$ of the LLOQ areas.

\section{RBC-TGN quantification}

RBC-TGN was quantified using LC-MS/MS, as described previously [22-24]. The LLOQ was $0.1 \mu \mathrm{mol} / \mathrm{L}$ for RBC-TGN (level corresponding to $\left.\sim 10 \mathrm{pmol} / 8 \times 10^{8} \mathrm{RBCs}\right)[23,24]$. The assay range was $0.1-10.0 \mu \mathrm{mol} / \mathrm{L}\left(10.0-1,000.0 \mathrm{pmol} / 8 \times 10^{8} \mathrm{RBCs}\right)$, and $\mathrm{CV}$ values for within- and between-run imprecisions were $<10 \%$ [18]. The method to measure RBC-TGN level was described previously [24].

\section{Statistical analysis and data availability}

Categorical variables are presented as frequencies and percentages. For quantitative non-normally distributed variables, we used non-parametric statistical methods, and data are expressed as medians and IQRs. We used non-parametric Spearman's rank test to investigate the correlation for all analyses [5]. Correlation scores from Spearman's rho $(\rho)$ was considered as follows: very weak (0.0-0.19), weak (0.2-0.39), moderate (0.40.59), strong (0.6-0.79), and very strong (0.8-1.0) [29]. The linear relationship between DNA-TG and RBC-TGN levels was tested using the linear regression model [5]. To investigate the correlation between DNA-TG and RBC-TGN levels, we used the last measurements at steady state for each individual. Repeated measures ANOVA was used to compare the dose and metabolites by genotype groups. To investigate the association between repeated measurements of DNA-TG and RBC-TGN levels, we used Bonferroni correction for repeated measures ANOVA. Statistical analysis was performed using MedCalc Statistical Software version 19.0.3 (MedCalc Software bvba, Ostend, Belgium; https://www.medcalc.org; 2019). $P<0.05$ was considered statistically significant. The datasets generated and/or analyzed in this study are available with the corresponding author and can be obtained on reasonable request.

\section{RESULTS}

\section{LC-MS/MS analysis of DNA-TG level}

Multiple reaction monitoring transitions of etheno-TG, etheno-G, and their ISs are illustrated in Fig. 1. The validated performance characteristics are summarized in Table 2. DNA-TG level as measured by LC-MS/MS ranged from 10.0 to $5,000 \mathrm{fmol} \mathrm{TG} / \mathrm{\mu g}$ DNA (coefficient of linearity $\left(R^{2}\right)>0.99$ ) for the standard curves. The precision and extraction recoveries were acceptable. There was no significant carry-over. There was no difference in the calibration slopes for etheno-TG in DNA or in distilled water, and
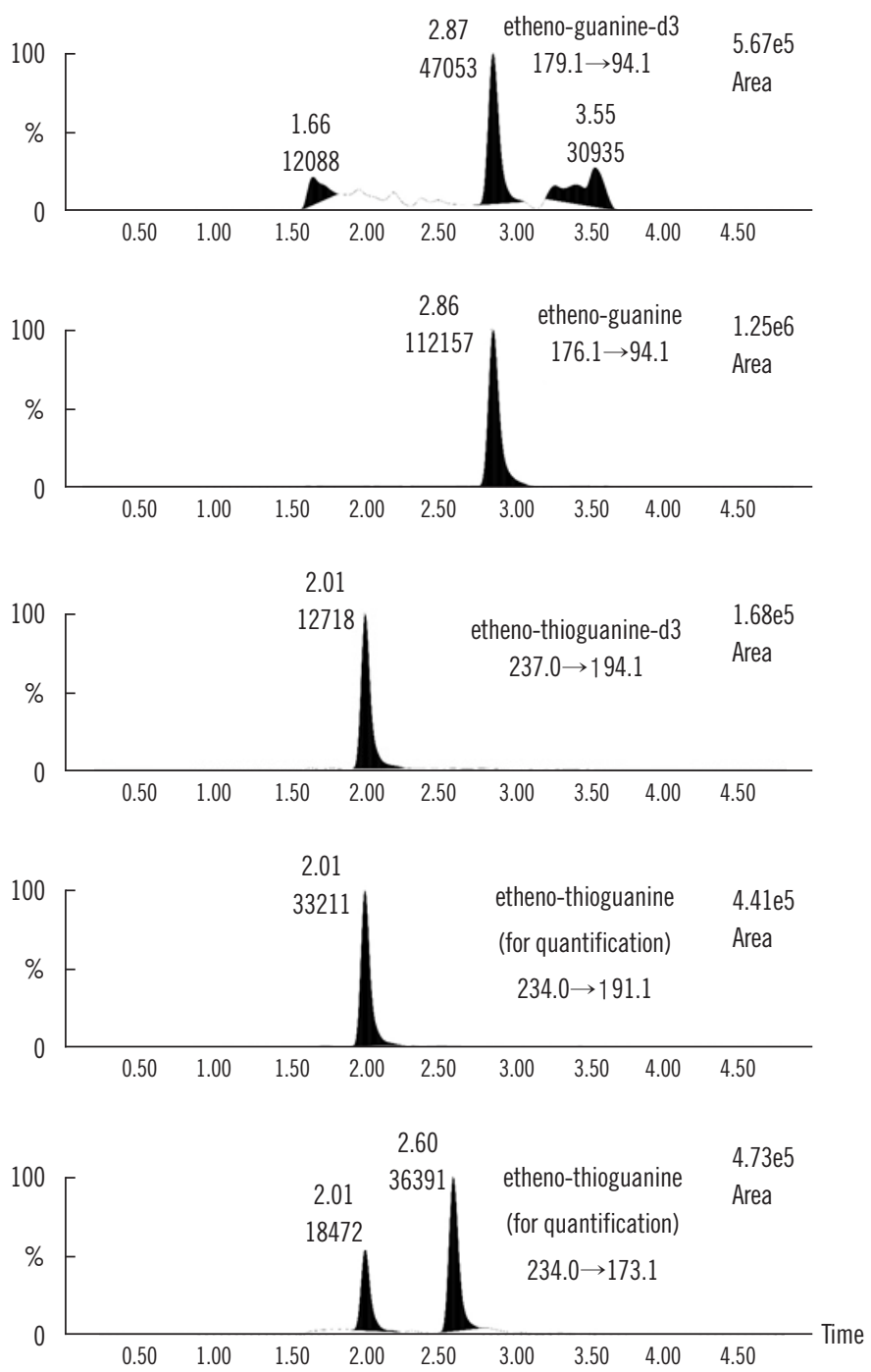

Fig. 1. Multiple reaction monitoring transitions for measurements of DNA-TG level using LC-MS/MS, presented as \% intensity vs. time (min).

Abbreviations: DNA-TG, DNA-incorporated 6-thioguanine; LC-MS/MS, liquid chromatography-tandem mass spectrometry. 
Table 2. Validated method specifications for LC-MS/MS for of DNA-TG quantification

\begin{tabular}{|c|c|c|c|}
\hline $\begin{array}{l}\text { Method } \\
\text { specification }\end{array}$ & $\begin{array}{l}\text { Levels and materials } \\
\text { tested and validated }\end{array}$ & Results & Acceptance criteria \\
\hline Linearity & $10-5,000 \mathrm{fmol}$ TG/mg DNA & $R^{2}=0.9987$, regression equation: $y=0.0036 x-0.0014$ & $R^{2}>0.99$ \\
\hline LLOQ & $10 \mathrm{fmol} \mathrm{TG} / \mathrm{mg}$ DNA & $\mathrm{S} / \mathrm{N}$ ratio 49 , bias $-1.2 \%$, CV $5.6 \%$ & S $/ \mathrm{N}$ ratio $>10$, bias $<20 \%, \mathrm{CV}<20 \%$ \\
\hline \multirow[t]{2}{*}{ Precision } & $80 \mathrm{fmol} \mathrm{TG/mg} \mathrm{DNA}$ & Within-run CV 3.4\%, between-run CV 5.8\% & CV $<15 \%$ \\
\hline & $800 \mathrm{fmol} \mathrm{TG} / \mathrm{mg}$ DNA & Within-run CV $4.9 \%$, between-run CV 5.3\% & \\
\hline \multirow[t]{4}{*}{ Accuracy } & $50 \mathrm{fmol} \mathrm{TG} / \mathrm{mg}$ DNA & Bias 3.5\% & Bias $<15 \%$ \\
\hline & $100 \mathrm{fmol} \mathrm{TG} / \mathrm{mg}$ DNA & Bias $-3.2 \%$ & \\
\hline & $250 \mathrm{fmol}$ TG/mg DNA & Bias $-10.4 \%$ & \\
\hline & $800 \mathrm{fmol}$ TG/mg DNA & Bias $-1.5 \%$ & \\
\hline Selectivity & Blank DNA & $<20 \%$ of analyte and $<5 \%$ of internal standard & $\begin{array}{l}\text { Response area of } \mathrm{LLOQ},<20 \% \text { of analyte } \\
\text { and }<5 \% \text { of internal standard }\end{array}$ \\
\hline Carry-over & $\begin{array}{l}\text { Blank DNA after control sample at 5,000 } \\
\text { fmol TG/mg DNA }\end{array}$ & Response area $<20 \%$ of LLOQ & Response area $<20 \%$ of LLOQ \\
\hline Extraction recovery & Pre-and post-SPE responses of e-TG & $\begin{array}{l}\text { Extraction recovery } 85.7-116.2 \% \text {, response area } \\
\text { CV } 5.1-12.1 \%\end{array}$ & Response area $\mathrm{CV}<15 \%$ \\
\hline Matrix effect & $\begin{array}{l}\text { Two linear calibration curves prepared in } \\
\text { DNA and in distilled water whose slopes } \\
\text { were compared }\end{array}$ & $\begin{array}{l}\text { Slope } 1.007 \text { for calibrators in DNA with deviation } \\
\text { percentage range } 0.72 \% \text { to }-7.24 \% \text { and slope } 1.010 \\
\text { for calibrators in distilled water with deviation } \\
\text { percentage range }-0.01 \% \text { to }-14.95 \%\end{array}$ & Deviation percentage $<15 \%$ \\
\hline
\end{tabular}

Abbreviations: DNA-TG, DNA-incorporated 6-thioguanine; TG, 6-thioguanine; e-TG, etheno-thioguanine; LC-MS/MS, liquid chromatography-tandem mass spectrometry; LLOQ, lower limit of quantification; $\mathrm{R}^{2}$, coefficient of linearity; S/N, signal to noise; SPE, solid-phase extraction.

Table 3. Characteristics of the 54 pediatric ALL patients

\begin{tabular}{lc}
\hline Characteristics & Results \\
\hline Male, N (\%) & $34(63.0)$ \\
Age, median (IQR), years & $6.5(4.0-14.0)$ \\
Number of thiopurine metabolite & $4.5(2.0-7.0)$ \\
$\quad$ measurements per patient, median (IQR) & \\
TPMT genotype, N (\%) & \\
${ }^{*} 1 /{ }^{*} 1$ (normal metabolizer) & $53(98.1)$ \\
${ }^{*} 1 /{ }^{*} 3$ (intermediate metabolizer) & $1(1.9)$ \\
$N U D T 15$ genotype, N (\%) & \\
$* 1 / * 1$ (normal metabolizer) & $43(79.6)$ \\
$* 1 / * 2$ (intermediate metabolizer) & $5(9.3)$ \\
$* 1 / * 3$ (intermediate metabolizer) & $2(3.7)$ \\
$* 1 / * 5$ (indeterminate phenotype) & $2(3.7)$ \\
$* 1 / * 6$ (indeterminate phenotype) & $2(3.7)$
\end{tabular}

TPMT and NUDT15 genotypes and phenotypes were evaluated according to the Clinical Pharmacogenetics Implementation Consortium guidelines $[10,28]$.

Abbreviations: ALL, acute lymphoblastic leukemia; IQR, interquartile range; TPMT, thiopurine S-methyltransferase.

there were no deviations in the responses, demonstrating the absence of a matrix effect and efficient normalization of etheno$G$ with regard to unexpected variation in the amount of DNA [1, 7].

\section{Correlation between RBC-TGN and DNA-TG levels and clinical applicability of TG-DNA measurement}

The median DNA-TG level was 106.0 (IQR, 75.8-150.9) fmol TG/ug DNA, and the median RBC-TGN level was 238.1 (IQR, 172.9-323.8) $\mathrm{pmol} / 8 \times 10^{8} \mathrm{RBCs}$.

A thorough review of the direct sequencing data for each subject revealed no novel variants in TPMT or NUDT15. Among the 54 pediatric patients, 42 had wild-type TPMT and NUDT15; 1 , the TPMT ${ }^{*} 1 /{ }^{*} 3 C$ genotype (TPMT intermediate metabolizer); and 11 , one variant NUDT15 allele (seven patients with NUDT15 intermediate metabolizer phenotype and four patients with NUDT15 indeterminate alleles) (Table 3) [10].

Correlation and linear relationship between DNA-TG levels and RBC-TGN levels by genotype groups are summarized in Fig. 2 and Supplemental Data Tables S1 and S2. DNA-TG levels and RBC-TGN levels showed moderate correlation in all 257 measurements ( $\rho=0.405, P<0.0001$ ). For the last measurements, NUDT15 intermediate metabolizers showed the strongest correlation between DNA-TG and RBC-TGN levels $(\rho=0.893, P<$ $0.0068)$. In NUDT15 intermediate metabolizers $\left({ }^{*} 1 /{ }^{*} 2\right.$ and ${ }^{*} 1 /$ $\left.{ }^{*} 3\right)$, there was a linear relationship between the DNA-TG and RBC-TGN levels $(P=0.0012)$ after Bonferroni correction.

A scatter diagram with regression lines for the last measure- 

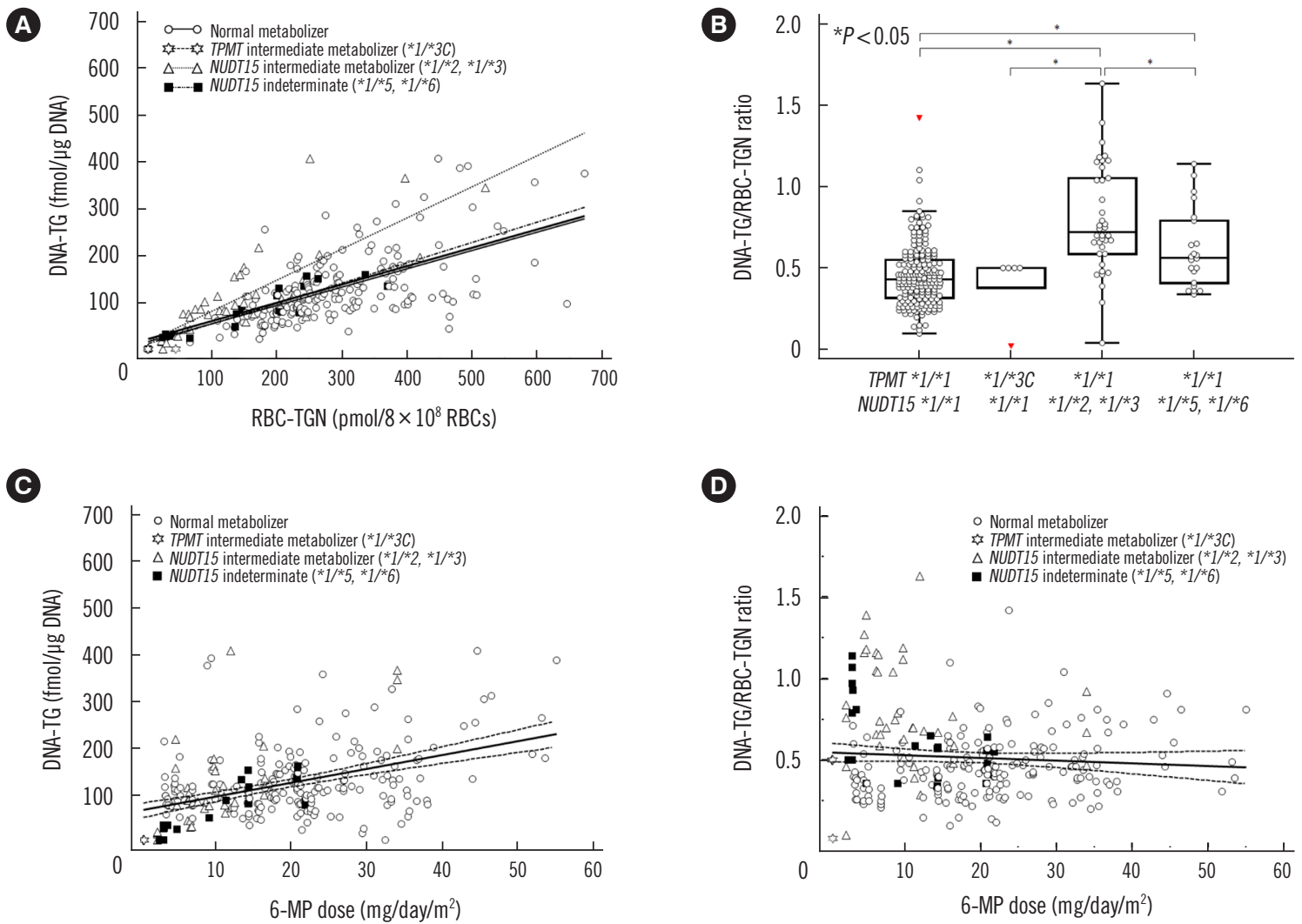

Fig. 2. Association between DNA-TG and RBC-TGN levels and their relationship with 6-MP dose $\left(\mathrm{mg} / \mathrm{day} / \mathrm{m}^{2}\right)$ according to TPMT and NUDT15 variant alleles. (A) Association between DNA-TG and RBC-TGN levels, with regression lines for all 257 measurements at steady state (bold straight solid line) and according to subgroups (light straight solid line for normal metabolizers, stiff-dotted line for NUDT15 intermediate metabolizers, including * $1 /{ }^{*} 2$ and ${ }^{*} 1 /{ }^{*} 3$, and dash-dotted line for measurements in subjects with NUDT15 indeterminate alleles, including ${ }^{*} 1 /{ }^{*} 5$ and ${ }^{*} 1 /{ }^{*} 6$ ). (B) DNA-TG/RBC-TGN ratio by subgroup (C) Association between 6-MP dose and DNA-TG levels. (D) DNA-TG/RBC-TGN ratio with regression line (straight line) and 95\% confidence interval (dashed lines) for all results.

Abbreviations: DNA-e-TG, etheno-thioguanine DNA; RBC-TGN, erythrocyte 6-thioguanine nucleotides; 6-MP, mercaptopurine; DNA-TG, DNA-incorporated 6-thioguanine; TPMP, thiopurine S-methyltransferase.

ments at steady state, categorized according to the TPMT and NUDT15 genotypes, also revealed linear associations between DNA-TG and RBC-TGN levels in all 54 patients $\left(R^{2}=0.4955\right.$, $P<0.0001)$, in patients with wild-type TPMT and NUDT15 $\left(R^{2}=0.3860, P<0.0001\right)$, and in NUDT15 intermediate metabolizers $\left(R^{2}=0.8406, P<0.0118\right)$. DNA-TG/RBC-TGN ratios were higher in patients with NUDT15 variant alleles than in those with wild-type TPMT and NUDT15 ( $P<0.0001$, Fig. 2B). There was a moderate correlation between DNA-TG level and 6-MP dose $(\rho=0.417, P<0.0001)$, but not between the DNA-TG/ RBC-TGN ratio and 6-MP dose $(\rho=-0.0363, P<0.5625)$.

\section{DISCUSSION}

We successfully developed and validated an LC-MS/MS method for measuring DNA-TG level using derivatization and normaliza- tion with endogenous guanine isotope-labeled ISs in pediatric ALL patients, by modification of previous methods [1, 7]. The results obtained using this method showed good sensitivity for DNA-TG level even with only $1 \mu \mathrm{g}$ DNA collected from whole blood samples, with an LLOQ of $10 \mathrm{fmol}$ TG/ug DNA. We introduced a simpler method to quantify DNA-TG using etheno-G for efficient matrix-matched calibration compared with previous methods [7, 14, 26]. Pediatric ALL patients have low leukocyte counts due to chemotherapy and limited blood sampling volume. Therefore, the small sample volume of $1 \mu \mathrm{g}$ DNA validated in this study has advantages for therapeutic drug monitoring of mercaptopurine in routine clinical practice for pediatric ALL patients. Furthermore, two QC samples were used for every run of DNA-TG level measurement to ensure stable results [8].

Previous studies on DNA-TG level utilized different measurement methods with or without derivatization, TPMT or NUDT15 
Table 4. Previous studies on DNA-TG levels in ALL patients

\begin{tabular}{|c|c|c|c|c|c|c|}
\hline Reference & $\begin{array}{l}\text { Studied } \\
\text { region }\end{array}$ & $\begin{array}{c}\text { Study } \\
\text { subjects } \\
\text { (N) }\end{array}$ & 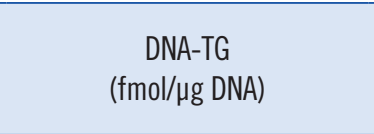 & RBC-TGN* & $\begin{array}{c}\text { Relationship between DNA-TG } \\
\text { and RBC-TGN }\end{array}$ & Genotypes \\
\hline $\begin{array}{l}\text { Jacobsen, et al., } \\
2012[7]\end{array}$ & Denmark & 18 & Median 377 (range 45-1,190) & Exact level NA & Correlated $\left(R^{2}=0.78\right)$ & NA \\
\hline $\begin{array}{l}\text { Nielsen, et al., } \\
2017 \text { [16] }\end{array}$ & $\begin{array}{l}\text { European } \\
\text { countries }\end{array}$ & 750 & $\begin{array}{l}\text { In maintenance phase 1: median } \\
326 \text { (IQR 229-457; range 23- } \\
1,591) \\
\text { In maintenance phase 2: median } \\
509 \text { (IQR 391-666; range 44- } \\
1,559)\end{array}$ & Exact level NA & $\begin{array}{l}\text { Positively associated using } \\
\text { multiple linear mixed effect } \\
\text { model estimate } 1.227(95 \% \mathrm{Cl} \\
1.175-1.281, P<0.0001) \text { in } \\
\text { exploratory cohort }(\mathrm{N}=42) \text { and } \\
1.137(95 \% \mathrm{Cl} 1.118-1.155 \\
P<0.0001) \text { in validation cohort } \\
(\mathrm{N}=304)\end{array}$ & TPMT genotypes \\
\hline \multirow[t]{3}{*}{$\begin{array}{l}\text { Moriyama, et al., } \\
2016[5]^{\ddagger}\end{array}$} & Japan & 32 & $\begin{array}{l}\text { Normal NUDT15 diplotypes: } \\
9.6 \pm 4.1\end{array}$ & NA & NA & $\begin{array}{l}\text { Both NUDT15 and } \\
\text { TPMT genotypes }\end{array}$ \\
\hline & & & $\begin{array}{l}\text { Children with one NUDT15 variant } \\
\text { allele: } 12.3 \pm 4.5\end{array}$ & & & \\
\hline & & & $\begin{array}{l}\text { One child with two NUDT15 } \\
\text { variant alleles: } 32.4\end{array}$ & & & \\
\hline This study & $\begin{array}{l}\text { South } \\
\text { Korea }\end{array}$ & 54 & $\begin{array}{l}\text { Median } 106.0 \text { (range }<10.0- \\
\text { 407.8) } \\
\text { Normal NUDT15 diplotypes: } 111.3 \\
\text { (IQR 79.1-156.4; range } \\
<10.0-407.5 \text { ) } \\
\text { Children with one NUDT15 variant } \\
\text { allele: 83.8 (IQR 38.6-134.4; } \\
\text { range }<10.0-407.8)\end{array}$ & $\begin{array}{l}\text { Median } 238.1 \text { (range }<10.0-672.5 \\
\mathrm{pmol} / 8 \times 10^{8} \mathrm{RBCs} \text { ) }\end{array}$ & $\begin{array}{l}\text { Correlated using Spearman rank } \\
\text { test }(R=0.68, P<0.0001)\end{array}$ & $\begin{array}{l}\text { Both NUDT15 and } \\
\text { TPMT genotypes (by } \\
\text { direct sequencing } \\
\text { to identify all } \\
\text { variants) }\end{array}$ \\
\hline
\end{tabular}

${ }^{*}$ RBC-TGN levels were differently expressed using different units in previous studies; ${ }^{\dagger}$ Ages of study subjects were not reported. Study subjects in the other studies were pediatric ALL patients. ${ }^{\ddagger}$ Mean $( \pm S D)$ DNA-TG level was expressed as fmol/ug DNA/mg mercaptopurine.

Abbreviations: ALL, acute lymphoblastic leukemia; 6-MP, mercaptopurine; Cl, confidence interval; DNA-TG, DNA-incorporated 6-thioguanine; Hgb, hemoglobin; IQR, interquartile range; NA, not available; TPMT, thiopurine S-methyltransferase; RBC, red blood cell; RBC-TGN, 6-thioguanine nucleotide in erythrocytes. 
genotype assays, and RBC-TGN measurement in different ethnic populations (Table 4) [1, 4, 5, 7, 14-16]. Different measurement units have been used for TG quantification in the litera-

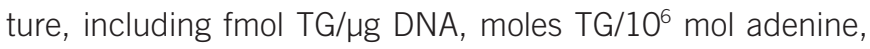
and fmol TG/mg DNA/mg 6-MP for DNA-TG, and nmol/mmol hemoglobin, pmol/4 $4 \times 10^{8} \mathrm{RBCs}$, and pmol/ $8 \times 10^{8} \mathrm{RBCs}$ for RBC-TGN [1, 4, 5, 7, 14-16]. These differences make it difficult to compare results from different study groups and obtain meaningful information on the utility of quantifying thiopurine metabolites for therapeutic drug monitoring. Owing to the lack of an analytical method for DNA-TG quantification in Korea, further studies are needed to elucidate the practical applicability of the developed method in clinical practice.

We applied our method to clinical samples from pediatric ALL patients for whom TPMT and NUDT15 genotyping data were available. The frequency of NUDT15 variant alleles ranges from $0.2 \%$ to $17.2 \%$ in different ethnic populations $[10,25,27]$. Variant alleles are more common in Asians and Hispanics, suggesting that the NUDT15 genotype is relevant to thiopurine metabolism and toxicity in these populations [10, 25, 27]. European studies reporting associations between DNA-TG and RBCTGN levels did not include information on NUDT15 genotypes $[1,7,16]$. In this study, patients with NUDT15 variants showed significantly higher DNA-TG/RBC-TGN ratios than the patients with wild-type NUDT15. This finding was comparable with the previous results in the Asian population, confirming the hypothesis that NUDT15 prevents the incorporation of thiopurine metabolites into DNA [4, 5].

The clinical impact of DNA-TG and RBC-TGN regarding NUDT15 and TPMT variants in pediatric ALL patients treated with thiopurines requires clarification in different ethnic populations [10]. Inconsistent results have been reported on RBCTGN and DNA-TG levels in patients with different TPMT and NUDT15 genotypes across different ethnic populations [4, 5, 7, 14-16]. Increase in NUDT15 variant alleles leads to increased TGN accumulation in the DNA in Japanese children $[4,5]$. Toxicity-related 6-MP dose reduction may more strongly lower the RBC-TGN level in patients with NUDT15 deficiency than in patients with normal NUDT15 metabolism, indicating that it would be more relevant to measure DNA-TG level than to measure RBC-TGN level $[1,4,5]$. Considering the different frequencies of NUDT15 variants in different ethnic populations and the differential accessibility to applicable measurement methods for DNA-TG and/or RBC-TG levels, future studies should clarify the relationships between TPMT and NUDT15 genotypes and metabolites, including DNA-TG and RBC-TGN [10].
The strengths of this study lie in its prospective nature and accurate genetic analysis of TPMT and NUDT15 genotypes via direct sequencing covering entire exons to identify all variants and define accurate genotypes. One limitation of this study is that the final DNA-TG levels might not be valid if recoveries of etheno-TG and etheno-G were not proportional. However, matrix effects during derivatization were referred to in a previous study that reported reproducible and acceptable calibration slopes without matrix effects [7]. Although matrix effects during derivatization was not directly evaluated in our study, we evaluated overall matrix effects by investigating calibration slopes from spiking TG into DNA and distilled water, which showed results similar to those observed in a previous study [7]. SPE recovery was acceptable; it was evaluated for etheno-TG according to a previous study describing limited recovery analysis, which relates to ion suppression, because it was not possible to obtain matrix free G-d3 [1]. Another limitation of our study is that we included only Korean patients; thus, our findings cannot be generalized to other ethnicities. As pharmacokinetics, pharmacodynamics, and variant allele frequencies differ across ethnic groups, studies in various ethnic groups will be needed to evaluate the generalizability of our findings.

In conclusion, we developed a simple, fast, sensitive, and accurate analytical method to measure DNA-TG level and successfully applied it to clinical samples from a Korean population. This study facilitates further studies on comprehensive therapeutic drug monitoring by measuring RBC-TGN and DNA-TG levels combined with pharmacogenetics-based testing, including TPMT and NUDT15 genotypes, in pediatric ALL patients across diverse populations.

\section{ACKNOWLEDGMENTS}

The authors thank Ms. Cho for her administrative support.

\section{AUTHOR CONTRIBUTIONS}

Conceptualization: JWL and SYL. Methodology: RC, MRC, JP and SYL. Software: RC and MRC. Validation: RC, MRC, JP and SYL. Formal analysis: RC and SYL. Investigation: RC, JWL, HYJ, HWC, HKH, HHK and ESY. Resources: JWL, HYJ, HWC, HKH, HHK and ESY. Data curation: RC and MRC. Writing-original draft preparation: RC. Writing-review and editing: RC, JWL and SYL. Visualization: RC. Supervision: JWL, HHK and SYL. Project administration: JWL and SYL. Funding acquisition: JWL and SYL. All authors have read and agreed to the published version 
of the manuscript.

\section{CONFLICTS OF INTEREST}

The authors declare no conflict of interest.

\section{RESEARCH FUNDING}

This study was supported by a grant from the Korean Foundation for Cancer Research (KFCR-2017-D-1). The funder was not involved in the study design, data interpretation, or writing of the manuscript.

\section{ORCID}

Rihwa Choi
Mi Ryung Chun
Jisook Park
Ji Won Lee
Hee Young Ju
Hee Won Cho
Ju Kyung Hyun
Hong Hoe Koo
Eun Sang Yi
Soo-Youn Lee

https://orcid.org/0000-0002-8266-2248 https://orcid.org/0000-0001-8225-7325 https://orcid.org/0000-0002-5329-9822 https://orcid.org/0000-0003-0084-1304 https://orcid.org/0000-0001-6744-0412 https://orcid.org/0000-0002-0440-645X https://orcid.org/0000-0001-9371-3808 https://orcid.org/0000-0001-8082-1412 https://orcid.org/0000-0001-8214-2106 https://orcid.org/0000-0001-7595-4042

\section{REFERENCES}

1. Coulthard SA, Berry P, McGarrity S, Ansari A, Redfern CPF. Liquid chromatography-mass spectrometry for measuring deoxythioguanosine in DNA from thiopurine-treated patients. J Chromatogr B Analyt Technol Biomed Life Sci 2016;1028:175-80.

2. Moon SY, Lim JH, Kim EH, Nam Y, Yu KS, Hong KT, et al. Quantification of thiopurine nucleotides in erythrocytes and clinical application to pediatric acute lymphoblastic leukemia. Ther Drug Monit 2019;41:7585.

3. Lampič K, Trontelj J, Prosen H, Drobne D, Šmid A, Vovk T. Determination of 6-thioguanine and 6-methylmercaptopurine in dried blood spots using liquid chromatography-tandem mass spectrometry: Method development, validation and clinical application. Clin Chim Acta 2019; 499:24-33.

4. Moriyama T, Nishii R, Lin TN, Kihira K, Toyoda H, Jacob N, et al. The effects of inherited NUDT15 polymorphisms on thiopurine active metabolites in Japanese children with acute lymphoblastic leukemia. Pharmacogenet Genomics 2017;27:236-9.

5. Moriyama T, Nishii R, Perez-Andreu V, Yang W, Klussmann FA, Zhao X, et al. NUDT15 polymorphisms alter thiopurine metabolism and hematopoietic toxicity. Nat Genet 2016;48:367-73.

6. CLSI. Liquid chromatography-mass spectrometry methods; approved guideline. CLSI document C62-A. Wayne, PA: Clinical and Laboratory Standards Institute. 2014.

7. Jacobsen JH, Schmiegelow K, Nersting J. Liquid chromatography-tan- dem mass spectrometry quantification of 6-thioguanine in DNA using endogenous guanine as internal standard. J Chromatogr B Analyt Technol Biomed Life Sci 2012;881-882:115-8.

8. Bioanalytical method validation guidance for industry, 2018. U.S. Department of Health and Human Services, Food and Drug Administration, Center for Drug Evaluation and Research (CDER, Center for Veterinary Medicine (CVM). https://www.fda.gov/regulatory-information/ search-fda-guidance-documents/bioanalytical-method-validation-guidance-industry (Updated on Feb 2020).

9. Zaza G, Cheok M, Krynetskaia N, Thorn C, Stocco G, Hebert JM, et al. Thiopurine pathway. Pharmacogenet Genomics 2010;20:573-4.

10. Relling MV, Schwab M, Whirl-Carrillo M, Suarez-Kurtz G, Pui CH, Stein $\mathrm{CM}$, et al. Clinical Pharmacogenetics Implementation Consortium guideline for thiopurine dosing based on TPMT and NUDT15 genotypes: 2018 update. Clin Pharmacol Ther 2019;105:1095-105.

11. Adam de Beaumais T, Fakhoury M, Medard Y, Azougagh S, Zhang D, Yakouben $\mathrm{K}$, et al. Determinants of mercaptopurine toxicity in paediatric acute lymphoblastic leukemia maintenance therapy. Br J Clin Pharmacol 2011;71:575-84.

12. Kim HY, Lee SH, Lee MN, Kim JW, Kim YH, Kim MJ, et al. Complete sequence-based screening of TPMT variants in the Korean population. Pharmacogenet Genomics 2015;25:143-6.

13. Yang JJ, Landier W, Yang W, Liu C, Hageman L, Cheng C, et al. Inherited NUDT15 variant is a genetic determinant of mercaptopurine intolerance in children with acute lymphoblastic leukemia. J Clin Oncol 2015; 33:1235-42.

14. Warren DJ, Andersen A, Slørdal L. Quantitation of 6-thioguanine residues in peripheral blood leukocyte DNA obtained from patients receiving 6-mercaptopurine-based maintenance therapy. Cancer Res 1995; 55:1670-4.

15. Nielsen SN, Grell K, Nersting J, Frandsen TL, Hjalgrim LL, Schmiegelow K. Measures of 6-mercaptopurine and methotrexate maintenance therapy intensity in childhood acute lymphoblastic leukemia. Cancer Chemother Pharmacol 2016;78:983-94.

16. Nielsen SN, Grell K, Nersting J, Abrahamsson J, Lund B, Kanerva J, et al. DNA-thioguanine nucleotide concentration and relapse-free survival during maintenance therapy of childhood acute lymphoblastic leukaemia (NOPHO ALL2008): a prospective substudy of a phase 3 trial. Lancet Oncol 2017; 18:515-24.

17. Draft guideline on bioanalytical method validation in pharmaceutical development, 2013. Japan: Ministry of Health and Welfare. http://www. nihs.go.jp/drug/BMV/BMV_draft_130415_E.pdf (Updated on Feb 2020).

18. Guideline on bioanalytical method validation. European Medicine Agency, 2012. https://www.ema.europa.eu/en/bioanalytical-method-validation (Updated on Feb 2020).

19. CLSI, Mass spectrometry in the clinical laboratory: general principles and guidance; approved guideline. CLSI document C50-A. Wayne, PA: Clinical and Laboratory Standards Institute. 2007.

20. Scientific Working Group for Forensic Toxicology. Scientific Working Group for Forensic Toxicology (SWGTOX) standard practices for method validation in forensic toxicology. J Anal Toxicol 2013;37:452-74.

21. Guideline on bioanalytical method validation, 2013. Ministry of Food and Drug Safety, Republic of Korea. https://www.mfds.go.kr/brd/ m_210/view.do?seq=13054 (Updated on Feb 2020).

22. Dervieux T, Meyer G, Barham R, Matsutani M, Barry M, Boulieu R, et al. Liquid chromatography-tandem mass spectrometry analysis of erythrocyte thiopurine nucleotides and effect of thiopurine methyltransferase gene variants on these metabolites in patients receiving azathioprine/6mercaptopurine therapy. Clin Chem 2005;51:2074-84. 
23. Lee MN, Kang B, Choi SY, Kim MJ, Woo SY, Kim JW, et al. Impact of genetic polymorphisms on 6-thioguanine nucleotide levels and toxicity in pediatric patients with IBD treated with azathioprine. Inflamm Bowel Dis 2015;21:2897-908.

24. Yoo IY, Lee K, Ji OJ, Woo HI, Lee SY. Evaluation of stability of thiopurine metabolites using a validated LC-MS/MS method. Ann Lab Med 2018; 38:255-60.

25. Kim HT, Choi R, Won HH, Choe YH, Kang B, Lee K, et al. NUDT15 genotype distributions in the Korean population. Pharmacogenet Genomics 2017;27:197-200.

26. Coulthard SA, Hogarth LA, Little M, Matheson EC, Redfern CP, Minto L, et al. The effect of thiopurine methyltransferase expression on sensitivity to thiopurine drugs. Mol Pharmacol 2002;62:102-9.

27. Choi R, Sohn I, Kim MJ, Woo HI, Lee JW, Ma Y, et al. Pathway genes and metabolites in thiopurine therapy in Korean children with acute lymphoblastic leukaemia. Br J Clin Pharmacol 2019;85:1585-97.

28. Yang JJ, Whirl-Carrillo M, Scott SA, Turner AJ, Schwab M, Tanaka Y, et al. Pharmacogene Variation Consortium gene introduction: NUDT15. Clin Pharmacol Ther 2019;105:1091

29. Selinger CP, Ochieng AO, George V, Leong RW. The accuracy of adherence self-report scales in patients on thiopurines for inflammatory bowel disease: a comparison with drug metabolite levels and medication possession ratios. Inflamm Bowel Dis 2019;25:919-924. 
Choi R, et al.

LC-MS/MS DNA-TG quantification

Supplemental Data Table S1. Correlation between DNA-TG and RBC-TGN levels

\begin{tabular}{|c|c|c|c|c|c|c|c|c|}
\hline & \multicolumn{4}{|c|}{ All measurements } & \multicolumn{4}{|c|}{ Last measurements } \\
\hline & Number & Coefficient $\rho$ & $95 \% \mathrm{Cl}$ for $\rho$ & $P$ & Number & Coefficient $\rho$ & $95 \%$ Cl for $\rho$ & $P$ \\
\hline All genotype & 257 & 0.405 & 0.297 to 0.502 & $<0.001$ & 54 & 0.683 & 0.508 to 0.804 & $<0.001$ \\
\hline $\operatorname{TPMT}^{*} 1 /{ }^{*} 1$ and $N U D T 15 * 1 /{ }^{*} 1$ & 190 & 0.711 & 0.633 to 0.775 & $<0.001$ & 41 & 0.569 & 0.317 to 0.746 & $<0.001$ \\
\hline TPMT $* 1 / * 3 C$ and $N U D T 15 * 1 / * 1$ & 5 & Not applicable & & & 1 & Not applicable & & \\
\hline $\begin{array}{l}\text { TPMT } * 1 /{ }^{*} 1 \text { and NUDT15 intermediate } \\
\text { metabolizer }\left({ }^{*} 1 / * 2 \text { and } * 1 / * 3\right)\end{array}$ & 38 & 0.377 & 0.0654 to 0.622 & 0.020 & 7 & 0.893 & 0.427 to 0.984 & 0.007 \\
\hline $\begin{array}{l}\text { TPMT }{ }^{*} 1 /{ }^{*} 1 \text { and NUDT15 indeterminate } \\
\text { genotypes }\left(* 1 / * 5 \text { and }{ }^{*} 1 /{ }^{*} 6\right)\end{array}$ & 22 & -0.174 & -0.555 to 0.267 & 0.438 & 4 & Not applicable & & \\
\hline
\end{tabular}

Abbreviations: Cl, confidence interval; DNA-TG, DNA-incorporated 6-thioguanine; RBC-TGN, erythrocyte 6-thioguanine nucleotides. 
Supplemental Data Table S2. Linear relationship between DNA-TG and RBC-TGN levels

\begin{tabular}{|c|c|c|c|c|c|c|c|c|}
\hline & & All measure & ements & & & Last measul & rements & \\
\hline & Number & $\begin{array}{l}\text { Regression } \\
\text { equation }\end{array}$ & $\begin{array}{l}\text { Coefficient of } \\
\text { determination } \\
\mathrm{R}^{2}\end{array}$ & $P$ & Number & $\begin{array}{l}\text { Regression } \\
\text { equation }\end{array}$ & $\begin{array}{l}\text { Coefficient of } \\
\text { determination } \\
\mathrm{R}^{2}\end{array}$ & $P$ \\
\hline All genotype & 257 & $y=21.909+0.392 x$ & 0.431 & $<0.001$ & 54 & $y=29.957+0.450 x$ & 0.496 & $<0.001$ \\
\hline TPMT $* 1 / * 1$ and NUDT15 * $1 / * 1$ & 190 & $y=17.712+0.387 x$ & 0.343 & $<0.001$ & 41 & $y=32.594+0.442 x$ & 0.386 & \\
\hline TPMT ${ }^{*} 1 / * 3 C$ and $N U D T 15 * 1 /{ }^{*} 1$ & 5 & Not applicable & & & 1 & Not applicable & & \\
\hline $\begin{array}{l}\text { TPMT }{ }^{*} 1 /{ }^{*} 1 \text { and NUDT15 intermediate } \\
\text { metabolizer }\left({ }^{*} 1 / * 2 \text { and } * 1 / * 3\right)\end{array}$ & 38 & $y=16.306+0.664 x$ & 0.641 & $<0.001$ & 7 & $y=-15.275+1.056 x$ & 0.749 & 0.012 \\
\hline $\begin{array}{l}T_{P M T}{ }^{*} 1 /{ }^{*} 1 \text { and NUDT15 indeterminate } \\
\text { genotypes }\left(* 1 /{ }^{*} 5 \text { and }{ }^{*} 1 /{ }^{*} 6\right)\end{array}$ & 22 & $y=11.699+0.435 x$ & 0.859 & $<0.001$ & 4 & $y=27.444+0.339 x$ & 0.841 & 0.083 \\
\hline
\end{tabular}

Abbreviations: Cl, confidence interval; DNA-TG, DNA-incorporated 6-thioguanine; RBC-TGN, erythrocyte 6-thioguanine nucleotides. 